\title{
KONTRIBUSI STRATEGI CONTEXTUAL TEACHING AND LEARNING (CTL) TERHADAP MOTIVASI BELAJAR SISWA KELAS V PADA MATA PELAJARAN ILMU PENGETAHUAN ALAM (IPA) DI MADRASAH IBTIDAIYAH
}

\author{
Abdul Razak'1), Sitti Rahmahwati2) \\ IAIN Samarinda \\ Email: razakabdul180290@gmail.com²), sitirahmahwatiii@gmail.com²)
}

Naskah diterima : 3 Februari 2019, direvisi : 1 April 2019, disetujui : 15 April 2019

\begin{abstract}
Pelajaran IPA dapat dijadikan wahana bagi siswa untuk mempelajari diri sendiri dengan alam sekitar yang selanjutnya dapat diterapkan dalam kehidupan sehari-hari. Melalui strategi pembelajaran contextual teaching and learningdapat memberi kontibusi terhadap motivasi belajar siswa kelas V di MIN 2 Samarinda. Sebab strategi pembelajaran CTL memiliki kelebihan di antaranya pembelajaran menjadi lebih bermakna dan riil,pembelajaran lebih produktif dan mampu menumbuhkan penguatan konsep siswa atau konstruktivisme. Adapun tujuan penelitian ini untuk mengetahui seberapa besar kontribusi strategi contextual teaching and learning (CTL) terhadap motivasi belajar siswa kelas V pada mata pelajaran Ilmu Pengetahuan Alam di Madrasah Ibtidaiyah. Penelitian ini adalah penelitian kuantitatif dengan satu variabel bebas dan satu variabel terikat yaitu strategi contextual teaching and learning (CTL) dan motivasi belajar siswa. Subjek penelitian ini adalah siswa kelas V Madrasah Ibtidaiyah dengan jumlah populasi sebanyak 115 siswa. Penarikan sampel dengan teknik proportionate stratified random sampling menggunakan rumus Taro Yamane atau Slovin dengan jumlah 53 responden. Adapun pengumpulan data menggunakan angket dan analisis data menggunakan koefisien korelasi product moment dengan bantuan program SPSS versi 20.0. Berdasarkan hasil analisis secara kuantitatif maka dapat disimpulkan bahwa terdapat kontribusi positif yang signifikan antara strategi contextual teaching and learning terhadapmotivasi belajar siswa kelas V pada mata pelajaran Ilmu Pengetahuan Alam di MIN 2 Samarinda dengan kategori sedang dengan nilai sig (2-tailed) $0.000<0.05$, nilai $\mathrm{r}$ hitung $=0.567>\mathrm{r}$ tabel $=0.271$ dengan derajat kebebasan (dk) yaitu $53-2=51$. Adapun hasil nilai t hitung $=4.918>\mathrm{t}$ tabel $=2,008$,sedangkan koefisien determinasi ( $\mathrm{r} 2$ ) menunjukkan persentase sumbangan strategi contextual teaching and learningterhadap motivasi belajar siswa sebesar 32.2\% dan 67,8\% ditentukan oleh faktor lain.
\end{abstract}

Keywords: Kontribusi Strategi, CTL, Motivasi Belajar,

Pengutipan: Abdul Razak \& Sitti Rahmawati. (2019). Kontribusi Strategi Contextual Teaching and Learning (CTL) Terhadap Motivasi Belajar Siswa Kelas V pada Mata Pelajaranilmu Pengetabuan Alam (IPA) di Madrasah Ibtidaiyah Negeri 2 Samarinda. JMIE: Journal of Madrasah Ibtidaiyah Education,3(1), 2019, 1-10. jmie.v3i1.88.

Permalink/DOI: http://dx.doi.org/ 10.32934/jmie.v3i1.88 


\section{PENDAHULUAN}

Pendidikan mempunyai peran yang sangat urgen untuk menjamin perkembangan dan kelangsungan kehidupan suatu bangsa. Pendidikan juga menjadi tolak ukur memajukan suatu bangsa, dan menjadi cermin kepribadian masyarakatnya. Untuk mencapai tujuan pembangunan pendidikan, pemerintah melakukan segala upaya untuk meningkatkan kualitas pendidikan.

Pendidikan adalah usaha sadar dan terencana untuk mewujudkan suasana belajar dan proses pembelajaran agar siswa secara aktif mengembangkan potensi dirinya untuk memiliki kekuatan spiritual keagamaan, pengendalian diri, kepribadian, kecerdasan, akhlak mulia serta ketrampilan yang diperlukan dirinya, masyarakat, bangsa dan negara (UU No. 20 Thn 2003). Pendidikan nasional adalah pendidikan yang berdasarkan Pancasila dan Undang- Undang Dasar Negara Republik Indonesia Tahun 1945 yang berakar pada nilai-nilai agama, kebudayaan nasional Indonesia dan tanggap terhadap tuntutan perubahan zaman (DItjen Pendis, 2006: 46).

Berbicara tentang pendidikan, kita tidak bisa melupakan sosok seorang guru. Berhasil atau tidak suatu pendidikan dalam suatu negara salah satunya adalah karena guru. Guru mempunyai peranan yang sangat penting dalam perkembangan dan kemajuan siswanya. Dari siniguru dituntut untuk dapat menjalankan tugas dengan sebaik-baiknya. Untuk dapat mencapai tujuan pembelajaran yang diharapkan guru harus pandai memilih model atau strategi pembelajaran yang tepat dan sesuai dengan kebutuhan siswa. Keberhasilan proses belajar mengajar di kelas sebagian besar tergantung pada guru, karena guru dapat menciptakan situasi belajar yang menyenangkan atau membosankan.

Oleh karena itu, peran guru dalam rangka meningkatkan mutu pendidikan dan pengajaran salah satunya adalah dengan memilih strategi atau cara dalam menyampaikan materi pelajaran agar diperoleh peningkatan prestasi belajar siswa. Misalnya dengan membimbing siswa untuk bersama-sama terlibat aktif dalam proses pembelajaran dan mampu membantu siswa berkembang sesuai dengan taraf intelektualnya akan lebih menguatkan pemahaman siswa terhadap konsep-konsep yang diajarkan.

Kaitannya dengan hal tersebut di atas maka sebagai seorang guru dalam menyampaikan ilmu pengetahuan dituntut untuk selalu menggunakan strategi pembelajaran yang tepat. Seorang guru harus mampu memilih dan memilah strategi apa yang akan digunakan dalam pembelajaran. Strategi tersebut haruslah disesuaikan dengan materi yang akan diajarkan. Sehingga jika guru memilih dan menetapkan strategi yang tepat dalam pembelajaran maka akan dapat meningkatkan hasil belajar siswa secara efektif.

Keberhasilan proses pembelajaran dipengaruhi oleh banyak faktor, sebab guru berhadapan langsung dengan siswa. Dalamprosespembelajaran, guru sebagai perencana sekaligus pelaksana pembelajaran dituntut untuk memahami secara benar baik kurikulum, karakteristik siswa dan strategi pembelajaran. Dengan demikian gurulah yang menjadi penentu dalam mencapai keberhasilan pembelajaran. Karena di tangan guru yang baik keterbatasan 
apapun yang mempengaruhi proses pendidikan dapat di atasi atau diminimalkan (Roqib dkk, 2009: 3).

Agar dapat mencapai keberhasilan pembelajaran yang maksimal, guru harus memahami faktor-faktor yang mempengaruhi keberhasilan pembelajaran tersebut.

Faktor-faktor yang mempengaruhi keberhasilan pembelajaran dapat dibagi menjadi 2 bagian besar, yaitu faktor internal dan faktor eksternal. Faktor internal adalah faktor yang terdapat di dalam diri individu itu sendiri, seperti kesehatan jasmani dan rohani, kecerdasan (intelegensia), daya ingat, kemauan, dan bakat. Sedangkan faktor eksternal adalah faktor yang berasal dari luar diri individu yang belajar, seperti keadaan lingkungan rumah, sekolah, masyarakat, dan segala sesuatu yang berhubungan dengan semua lingkungan tersebut (Thursan, 2001: 6).

Berdasarkan faktor tersebut di atas, maka seorang guru dituntut untuk kreatif dalam pembelajaran. Guru harus dapat menciptakan suasana pembelajaran yang interaktif, edukatif dan menyenangkan. Hal ini dapat guru lakukan dengan melakukan berbagai macam strategi pembelajaran. dengan menggunakan strategi pembelajaran yang tepat akan meningkatkan motivasi belajar siswa.

Pada mulanya istilah strategi banyak digunakan dalam dunia militer yang diartikan sebagai cara penggunaan seluruh kekuatan militer untuk memenangkan suatu peperangan. Sekarang, istilah strategi banyak digunakan dalam berbagai bidang kegiatan yang bertujuan memperoleh kesuksesan atau keberhasilan dalam mencapai tujuan.Misalnya seorang manajer atau pimpinan perusahaan yang menginginkan keuntungan dan kesuksesan yang besar akan menerapkan suatu strategi dalam mencapai tujuannya itu. Begitu juga seorang guru yang mengharapkan hasil yang baik dalam proses pembelajaran,sehingga akan menerapkan suatu strategi pembelajaran yang baik dan tepat.

Strategi menurut Marrus dalam Husein, adalah suatu proses penentuan rencana para pemimpin puncak yang berfokus pada tujuan jangka panjang organisasi disertai penyusunan suatu cara atau upaya bagaimana agar tujuan tersebut dapat dicapai (Husein, 2001: 31).

Dewasa ini banyak dikembangkan strategi-strategi baru yang dapat diterapkan dalam pembelajaran. Strategi tersebut merupakan strategi pembelajaran aktif yang berpusat pada siswa (student centered). Pada strategi tersebut siswa diminta berpartisipasi aktif dan terlibat langsung dalam pembelajaran. Dengan strategi yang tepat dan menyenangkan, maka akan lebih memudahkan guru untuk mencapai tujuan pembelajaran.

Dalam proses pembelajaran banyak strategi pembelajaran yang dituangkan dalam model pembelajaran yang dipilih sesuai dengan materi yang disampaikan oleh guru. Ada macammacammodel pembelajaran tersebut antara lain: Model Pembelajaran Quantum, Model Pembelajaran Terpadu, Model Pembelajaran Berbasis masalah (PBL), Model Pembelajaran Langsung (Direct Instruction), Model Pembelajaran diskusi,Model Pembelajaran Kooperatif dan Model Pembelajaran Kontekstual. 
Berbagai macam model pembelajaran tersebut di atas, maka pemilihan strategi pembelajaran idealnya disesuaikan dengan sifat materi, karakteristik siswa, lingkungan sekolah, dsb. Penggunaan strategi pembelajaran yang tepat tentunya dapat memberikan motivasi untuk belajar dan merangsang siswa untuk belajar aktif. Strategi pembelajaran Contextual Teaching and Learning (CTL) dianggap salah satu strategi pembelajaran yang bagus untuk mengatasi rendahnya daya serap siswa.Menurut Daryanto, CTL adalah suatu proses pendidikan yang holistik dan bertujuan memotivasi siswa untuk memahami makna materi pelajaran yang dipelajarinya dengan mengaitkan materi tersebut dengan konteks kehidupannya mereka sehari-hari sehingga siswa memiliki pengetahuan/keterampilan yang secara fleksibel dapat diterapkan (Daryanto, 2012: 156).

Contextual Teaching and Learning (CTL) memiliki tujuan yaitu dapat membantu para siswa dengan cara yang tepat untuk mengaitkan makna pada pelajaran yangditerima. Ketika para siswa menemukan makna di dalam pelajaran mereka, mereka akan belajar dan mengingat apa yang mereka pelajari. CTL membuat siswa mampu menghubungkan isi dari subjek-subjek akademik dengan konteks kehidupan seharian mereka untuk menemukan makna.Hal itu memperluas konteks pribadi mereka.Kemudian, dengan memberikan pengalaman-pengalaman baru yang merangsang otak membuat hubungan-hubungan baru, kita membantu mereka menemukan makna baru (Elaine, 2007: 46). Melalui proses penerapan kompetensi dalam kehidupan seharihari, siswa akan merasakan pentingnya belajar, dan mereka akan memperoleh makna yang mendalam terhadap apa yang dipelajarinya.

Berkaitan dengan hal tersebut maka CTL menjadi penting untuk dipahami sebagai strategi pembelajaran yang bukan sekedar objek akan tetapi mampu berperan sebagai subyek, dengan dorongan dari guru, siswa mengkonstruksi pelajaran dalam benak siswa, jadi siswa tidak hanya sekedar menghafal fakta-fakta, tetapi siswa dituntut untuk mengalami dan akhirnya menjadi tertarik untuk menerapkannya. Dengan demikian strategi CTL diharapkan dapat memberi kontribusi terhadap motivasi belajar siswa.

Motivasi belajar menurut Uno adalah dorongan internal dan eksternal pada siswa-siswa yangsedang belajar untuk mengadakan perubahan tingkah laku, padaumumnya dengan beberapa indikator atau unsur yang mendukung. Hal ini mempunyai peranan besar dalam keberhasilan seseorang dalam belajar. Indikator motivasi belajar dapat diklasifikasikan sebagai berikut:(1) adanya hasrat dan keinginan berhasil; (2) adanya dorongan dan kebutuhan dalam belajar; (3) adanya harapan dan cita-cita masa depan; (4) adanya perhargaan dalam belajar; (5) adanya kegiatan yang menarik dalam belajar; (6) adanya lingkungan belajar yang kondusif, sehingga memungkinkan seseorang siswa dapat belajar dengan baik (Uno, 2013: 23).

Menurut Printich \& Schunk dalam Wahyuni, siswa yang termotivasi belajar akan menunjukkan antusiasme terhadap aktivitas belajar, serta memberikan perhatian penuh terhadap apa yang diinstruksikan oleh guru, serta memiliki komitmen yang tinggi untuk mencapai tujuan belajar (Esa, 2009: 39). 
Motivasi dapat berperan dalam penguatan belajar, apabila siswa dihadapkan pada suatu masalah yang memerlukan pemecahan dan hanya dapatdipecahkan melalui hal-hal yang pernah dilaluinya. Oleh karena itu,guru perlu melakukan variasi model pembelajaran sehingga dapat meningkatkan motivasi belajar siswa.

Motivasi belajar siswasalah satu menentukan tingkat berhasil atau kegagalan belajar siswa, belajar tanpa motivasi kiranya sulit untuk berhasil.Seseorang belajar dengan motivasi yang kuat akan melaksanakan kegiatan belajar dengan sungguh-sungguh. Sebaliknya, jika belajar dengan motivasi yang lemah akan malas bahkan tidak mampu mengerjakan tugas-tugas pelajaran dengan baik. Setiap pihak yang terlibat dalam proses belajar mengajar harus berusaha memperhatikan dan mencari cara untuk menumbuhkan, menjaga, serta mengarahkan motivasi belajar siswa salah satunya melalui strategi pembelajaran CTL pada mata pelajaran IPA di MIN 2 Samarinda.Sebabstrategi pembelajaran CTL memiliki kelebihan di antaranya, pertama pembelajaran menjadi lebih bermakna dan riil, artinya siswa dituntut untuk dapat menangkap hubungan antara pengalaman belajar di sekolah dengan kehidupan nyata. Kedua pembelajaran lebih produktif dan mampu menumbuhkan penguatan konsep kepada siswa karena CTL menganut aliran konstruktivisme, yaitu menganggap siswa dapat menemukan dan membangun pengetahuannya sendiri. Melalui landasan filosofis konstruktivisme siswa diharapkan belajar melalui "mengalami" bukan "menghafal".

IPA adalah mata pelajaran yang berkaitan dengan cara mencari tahu tentang alam secara sistematis sehingga IPA bukan saja hanya penguasaan kumpulan pengetahuan berupa faktafakta, konsep atau prinsip saja tetapi juga merupakan suatu proses penemuan. Pelajaran IPA dapat dijadikan wahana bagi siswa untuk mempelajari diri sendiri dengan alam sekitar yang selanjutnya dapat diterapkan dalam kehidupan sehari-hari.

Proses pembelajaran dengan menekankan pemberian pengalaman langsung akan memudahkan siswa dalam memperoleh pemahaman yang lebih mendalam tentang alam sekitar. Pembelajaran IPA sebaiknya dilakukan dengan cara menumbuhkan dan memberi pengalaman belajar secara langsung.

CTL telah dikembangkan di MIN 2 Samarinda khususnya pada pembelajaran IPA sejak mulai diberlakukannya kurikulum 2013. Tuntutan kurikulum tersebut, sehingga guru diberikan berbagai macam pelatihan dan pendidikan kaitannya dengan strategi dan model pembelajaran agar guru dapat melaksanakan kurikulum dengan baik.

Berdasarkan survey dan wawancara penulis, bahwa belajar IPA dengan CTL di MIN 2 Samarinda belum maksimal, sebab selama proses pembelajaran guru lebih berorientasi pada ceramah atau eksplanasi yaitu penjelasan biasa sehingga siswa masih bersifat pasif, disamping itu juga pembelajaran yang dikembangkan bersifat tektual dengan buku sebagai sumber pembelajaran utama dan kurang mengoptimalkan sumber belajar lain. Hal ini menyebabkan motivasi belajar siswa menjadi kurang optimal.Yang berakibat siswa tidak memiliki pemahaman yang konkrit tentang IPA yang bisa diaplikasikan dalam kehidupan sehari-hari. 
Sedangkan Djamarah dan Aswan mengemukakan pengertian strategi secara umum merupakan "suatu garis-garis besar haluan untuk bertindak dalam usaha mencapai sasaran yang telah ditentukan" (Djamarah dkk, 2006: 5).

Strategi pembelajaran adalah suatu kegiatan pembelajaran yang harus dikerjakan guru dan siswa agar tujuan pembelajaran dapat dicapai secara efektif dan efisien (Wina, 2006: 126).

Sama halnya menurut Trianto menjelaskan pengertian Contextual Teaching and Learning (CTL) adalah suatu konsepsi yang membantu guru mengaitkan konten mata pelajaran dengan situasi dunia nyata dan memotivasi siswa membuat hubungan antara pengetahuan dan penerapannya dalam kehidupan mereka sebagai anggota keluarga, warga negara, dan tenaga kerja (Trianto, 2010: 104-105).

\section{a. Konstruktivisme}

Belajar berdasarkan konstruktivisme adalah "mengonstruksi" pengetahuan. Pengetahuan dibangun melalui proses asimilasi dan akomodasi. Belajar dalam konteks konstruktivistik berangkat dari kenyataan bahwa pengetahuan itu terstruktur. konsep ini menuntun siwa untuk menyusun dan membangun makna atas pengalaman baru yang didasarkan pada pengetahuan tertentu. Pembelajaran dikemas menjadi proses "mengkonstruksi" bukan menerima pengetahuan.

b. Inquiry

Kata kunci pembelajaran kontekstual salah satunya adalah "penemuan". Belajar penemuan menunjuk pada proses dan hasil belajar. Belajar penemuan melibatkan siswa dalam keseluruhan proses metode keilmuan untuk menemukan pengetahuan baru atau memverifikasi pengetahuan lama serta mengintegrasikan aktivitas belajar siswa. Dengan demikian inquiry merupakan siklus proses dalam membangun pengetahuan atau konsep yang bermula dari melakukan observasi, bertanya, investigasi, analisis, kemudian membangun teori atau konsep.

c. Bertanya

Pembelajaran kontekstual dibangun melalui dialog interaktif melalui tanya jawab oleh keseluruhan unsur yang terlibat dalam komunitas belajar. Kegiatan bertanya penting untuk menggali informasi, mengonfirmasikan apa yang sudah diketahui, dan mengarahkan perhatian pada aspek yang belum diketahuinya. Bertanya sangat penting untuk melakukan elaborasi yaitu penambahan rincian, sehingga informasi baru akan menjadi lebih bermakna. Menurut Amin dalam Mulyanah, menyebutkan bahwa dalam konsep ini kegiatan tanya jawab yang dilakukan dengan baik oleh guru maupun siswa. Pertanyaan guru digunakan untuk memberikan kesempatan kepada siswa untuk berpikir secara kritis dan mengevaluasi cara berpikir siswa, sedangkan pertanyaan siswa merupakan wujud keingintahuan sebagai proses perpindahan berlangsung dari pengamatan menjadi pemahaman (Mulyanah, 2013: 19-20).

\section{d. Masyarakat Belajar}


Pembelajaran kontekstual menekankan arti penting pembelajaran sebagai proses sosial. Melalui interaksi dalam komunitas belajar proses dan hasil belajar menjadi lebih bermakna. Dalam prakteknya masyarakat belajar terwujud dalam pembentukan kelompok kecil, pembentukan kelompok besar, mendatangkan ahli di kelas, bekerja sama dengan kelas paralel, bekerja kelompok dengan kelas di atasnya, bekerja sama dengan masyarakat. Tujuannya adalah berfungsi sebagai wadah komunikasi untuk berbagi pengalaman dan gagasan. Siswa dapat bertukar pengalaman dengan yang lainnya dan dapat berbagi ide dengan yang lain tentang apa yang sedang dialami atau dilakukan

e. Pemodelan

Pembelajaran kontekstual menekankan arti penting pendemonstrasian terhadap hal yang dipelajari siswa. Pemodelan memusatkan pada arti penting pengetahuan prosedural. Melalui pemodelan siswa dapat meniru terhadap hal yang dimodelkan. Artinya dalam konsep ini kegiatan mendemonstrasikan suatu kerja agar siswa dapat mencontoh, belajar atau melakukan sesuatu sesuai dengan model yang diberikan (Mulyanah, 2013: 19-20).

f. Refleksi

Refleksi yaitu bagian penting dalam pembelajaran kontekstual. Refleksi merupakan upaya untuk melihat kembali, menganalisis kembali, mengklarifikasi kembali, dan mengevaluasi hal-hal yang telah dipelajari. Kegiatan dan pengalaman yang bertujuan untuk mengidentifikasi hal yang sudah diketahui dan hal yang belum diketahui agar dapat dilakukan suatu tindakan penyempurnaan.

g. Penilaian autentik

Penilaian autentik adalah upaya pengumpulan berbagai data yang bisa memberikan gambaran perkembangan belajar siswa. Data dikumpulkan dari kegiatan nyata yang dikerjakan siswa pada saat melakukan pembelajaran.

\section{METODE PENELITIAN}

Metode penelitain yang digunakan pada penelitian ini adalah pendekatan kuantitatif dan penelitian ini dilakukan di MIN 2 Samarinda di Jalan Sultan Alimuddin RT. 26 Kelurahan Selili Kecamatan Samarinda Ilir. Populasi dalam penelitian ini adalah seluruh siswa kelas V MIN 2 Samarinda yang berjumlah 115 siswa sebagai responden. Karena jumlah sampel melebihi dari 100, maka penarikan sampel dalam penelitian ini menggunakan teknik proportionate stratified random sampling menggunakan rumus Taro Yamane atau Slovin dengan jumlah 53 responden. Adapun pengumpulan data menggunakan angket dan analisis data menggunakan koefisien korelasi product moment dengan bantuan program SPSS versi 20.0.. 


\section{HASIL PENELITIAN DAN PEMBAHASAN}

Berdasarkan hasil analisis data, maka diperoleh gambaran bahwa variabel yang diuji ternyata memiliki kontribusi yang positif dan signifikan. Pembahasan hasil analisis korelasi akan disajikan sebagai berikut:

1. Kontibusi Strategi Contextual Teaching and Learning Terhadap Motivasi Belajar Siswa Kelas V Pada Mata Pelajaran Ilmu Pengetahuan Alam di MIN 2 Samarinda

Dalam proses pembelajaran banyak strategi pembelajaran yang dituangkan dalam model pembelajaran yang dipilih sesuai dengan materi yang disampaikan oleh guru. Berbagai macam model pembelajaran tersebut di atas, maka pemilihan strategi pembelajaran idealnya disesuaikan dengan sifat materi, karakteristik siswa, lingkungan sekolah, dsb. Penggunaan strategi pembelajaran yang tepat tentunya dapat memberikan motivasi untuk belajar dan merangsang siswa untuk belajar aktif. Strategi pembelajaran Contextual Teaching and Learning (CTL) dianggap salah satu strategi pembelajaran yang bagus untuk mengatasi rendahnya daya serap siswa. Menurut Daryanto contextual teaching and learning (CTL) adalah suatu proses pendidikan yang holistik dan bertujuan memotivasi siswa untuk memahami makna materi pelajaran yang dipelajarinya dengan mengaitkan materi tersebut dengan konteks kehidupannya mereka sehari-hari sehingga siswa memiliki pengetahuan/keterampilan yang secara fleksibel dapat diterapkan (Daryanto, 2012: 156). Trianto menambahkan bahwa contextual teaching and learning (CTL) adalah suatu konsepsi yang membantu guru mengaitkan konten mata pelajaran dengan situasi dunia nyata dan memotivasi siswa membuat hubungan antara pengetahuan dan penerapannya dalam kehidupan mereka sebagai anggota keluarga, warga negara, dan tenaga kerja (Trianto, 2010: 104-105).

Contextual Teaching and Learning (CTL) memiliki tujuan yaitu dapat membantu para siswa dengan cara yang tepat untuk mengaitkan makna pada pelajaran yang diterima. Ketika para siswa menemukan makna di dalam pelajaran mereka, mereka akan belajar dan mengingat apa yang mereka pelajari. CTL membuat siswa mampu menghubungkan isi dari subjek-subjek akademik dengan konteks kehidupan seharian mereka untuk menemukan makna. Hal itu memperluas konteks pribadi mereka. Kemudian, dengan memberikan pengalaman-pengalaman baru yang merangsang otak membuat hubungan-hubungan baru, kita membantu mereka menemukan makna baru (Elaine, 2007: 64). Melalui proses penerapan kompetensi dalam kehidupan sehari-hari, siswa akan merasakan pentingnya belajar, dan mereka akan memperoleh makna yang mendalam terhadap apa yang dipelajarinya.

Kaitannya dengan hal tersebut indikator-indikator strategi contextual teaching and learning dapat memberikan kontribusi terhadap motivasi belajar siswa yaitu hakikat belajar, model pembelajaran, kegiatan pembelajaran, kebermaknaan belajar, tindakan dan perilaku siswa dan tujuan hasil belajar. 
Motivasi dapat berperan dalam penguatan belajar, apabila siswa dihadapkan pada suatu masalah yang memerlukan pemecahan dan hanya dapat dipecahkan melalui hal-hal yang pernah dilaluinya. Oleh karena itu, guru perlu melakukan variasi model pembelajaran sehingga dapat meningkatkan motivasi belajar siswa.

Motivasi belajar menurut Uno adalah dorongan internal dan eksternal pada siswasiswa yang sedang belajar untuk mengadakan perubahan tingkah laku, pada umumnya dengan beberapa indikator atau unsur yang mendukung. Hal ini mempunyai peranan besar dalam keberhasilan seseorang dalam belajar. Indikator motivasi belajar dapat diklasifikasikan sebagai berikut:(1) adanya hasrat dan keinginan berhasil; (2) adanya dorongan dan kebutuhan dalam belajar; (3) adanya harapan dan cita-cita masa depan; (4) adanya perhargaan dalam belajar; (5) adanya kegiatan yang menarik dalam belajar; (6) adanya lingkungan belajar yang kondusif, sehingga memungkinkan seseorang siswa dapat belajar dengan baik (Uni, 2013: 23).

Motivasi ditandai oleh reaksi-reaksi untuk mencapai tujuan. Pribadi yang bermotivasi memberikan respon-respon kearah suatu tujuan tertentu (Hamalik, 2014: 106). Bermula dari motivasi belajar seseorang memiliki semangat untuk menjadi lebih baik dari kegiatan belajar. Dengan demikian dapat dikatakan bahwa tujuan motivasi adalah untuk menggerakkan atau mendorong seseorang agar timbul keinginan dan kemauan untuk melakukan sesuatu sehingga dapat diperoleh hasil dan mencapai tujuan tertentu.

Berdasarkan hasil penelitian menunjukkan bahwa terdapat kontibusi positif yang signifikan antara strategi contextual teaching and learning terhadap motivasi belajar siswa kelas $\mathrm{V}$ pada mata pelajaran Ilmu Pengetahuan Alam di MIN 2 Samarinda pada tingkat kontribusi sedang dengan $r$ hitung $=0,567>r$ tabel $=0,271$.

Hasil analisis tersebut di atas menunjukkan bahwa terjadi kontribusi sedang antara strategi contextual teaching and learning terhadap motivasi belajar siswa kelas V pada mata pelajaran Ilmu Pengetahuan Alam di MIN 2 Samarinda karena 0,567 berada pada interval $0,40-0,599$.

Selanjutnya dari hasil penelitian uji $t$ diketahui bahwa variabel strategi contextual teaching and learning $(\mathrm{X})$ terhadap variabel motivasi belajar siswa $(\mathrm{Y})$, dengan nilai signifikan $0,000<0,05$, sedangkan hasil nilai $t$ bitung $=4.918$. Jika dibandingkan dengan nilai $t$ tabel dikonsultasikan dengan $t$ tabel product moment dengan taraf signifikan $5 \%$ dan derajat kebebasan 53-2 = 51 adalah 2,008.

Hasil analisis uji signifikansi menunjukkan bahwa variabel strategi contextual teaching and learning berkontribusi signifikan terhadap variabel motivasi belajar siswa $(\mathrm{Y})$ karena hasil $t$ hitung $=4,918>t$ tabel $=2,008$.

2. Koefisien Determinasi Kontibusi Strategi Contextual Teaching and Learning Terhadap Motivasi Belajar Siswa Kelas V Pada Mata Pelajaran Ilmu Pengetahuan Alam di MIN 2 Samarinda 
Berdasarkan hasil penelitian tentang koefisien determinasi kontribusi strategi contextual teaching and learning terhadap motivasi belajar siswa diketahui sebesar $=0,322$ karena 0,567 dikuadratkan. Hasil analisis tersebut menunjukkan bahwa varian yang terjadi pada variabel motivasi belajar siswa 32,2\% ditentukan oleh varian strategi contextual teaching and learning sedangkan 67,8\% ditentukan oleh faktor lain antara lain model pembelajaran lain, fasilitas belajar, sarana dan prasarana, pengelolaan kelas, lingkungan belajar siswa dan lain-lain.

Berdasarkan hasil penelitian dan analisis data tersebut dapat di simpulkan bahwa terdapat kontribusi positif yang signifikan antara strategi contextual teaching and learning terhadap motivasi belajar siswa kelas V pada mata pelajaran Ilmu Pengetahuan Alam di MIN 2 Samarinda.

\section{SIMPULAN DAN SARAN}

1. Bagi guru hendaknya meningkatkan penggunaan strategi contextual teaching and learning (CTL) dalam memotivasi belajar siswa pada mata pelajaran IPA.

2. Bagi siswa diharapkan dapat mengikuti pembelajaran dengan strategi contextual teaching and learning (CTL) secara maksimal.

3. Bagi madrasah hendaknya memberikan fasilitas pembelajaran serta mengalokasikan dana untuk pengadaan sarana dan prasarana guna memudahkan dalam melaksanakan model pembelajaran di madrasah.

\section{DAFTAR PUSTAKA}

Daryanto. Model Pembelajaran Inovatif, Yogyakarta; Gava Media, 2012.

Dimyati dan Mudjiono, Belajar dan Pembelajaran, Jakarta: PT. Rineka Cipta, 2015.

Djamarah, Syaiful Bahri \& Aswin Zain, Strategi Belajar Mengajar, Jakarta; Rineka Cipta, 2006.

Jhonson, Elaine B., Contextual Teaching And Learning: Menjadikan Kegiatan Belajar Mengajar Mengasyikkan Dan Bermakna, terj.Ibnu Setiawan, Bandung: Kaifa, 2007.

Roqib, Moh. dan Nur Fuadi, Kepribadian Guru, Upaya Mengembangkan Kepribadian Guru yang Sehat di Masa Depan, Yogyakarta: Grafindo Litera Media, 2009.

Thursan Hakim, Belajar Secara Efektif (Jakarta: Puspa Suara, 2001 ) hal 6

Umar, Husein, Strategic Management In Action, Jakarta; Gramedia Pustaka Utama, 2001.

Nasional, Jakarta; Sinar Grafika 2003.

Undang-Undang Sistem Pendidikan Nomor 20 Tahun 2003, Jakarta: Ditjen Pendis, 2006.

Uno, Hamzah B., Model Pembelajaran, Jakarta; PT. Bumi Aksara, 2009.

----------, Teori Motivasi dan Pengukurannya, Analisis Di Bidang Pendidikan, Cet.10, Jakarta; PT. Bumi Aksara, 2013.

Wahyuni, Esa Nur, Motivasi dalam Pembelajaran, Malang: UIN Malang Press, 2009. 